\title{
PEMBELAJARAN FISIKA MELALUI PEMROSESAN TOP DOWN BERBASIS SCAFFOLDING UNTUK MELATIHKAN KETERAMPILAN BERPIKIR KRITIS
}

\author{
Muhammad Aqil Rusli ${ }^{1}$ \\ Prabowo \\ Wahono Widodo ${ }^{2}$ \\ ${ }^{1}$ Pendidikan Kimia, FKIP Unhalu \\ ${ }^{2}$ Dosen Prodi Pendidikan Sains Program Pascasarjana Unesa \\ e-mail:aqil.rusli@yahoo.com
}

\begin{abstract}
This research was developmental research conducted to understanding the effectiveness of instructional physics through topdown approach based on scaffolding to practice critical thinking skills. The data of initial developmental testing consisted of learning processes, student activities, and student responses obtained from observation sheet while critical thinking skills gained from the test of critical thinking skills. The initial developmental testing resulted that student's dominant activities was discussion and concept exploration. Students' response to learning was very well where $60 \%$ of students said that it was very easy to understand how teachers teach. For critical thinking skills, students were still in the category of limited proficiency to some proficiency category
\end{abstract}

Key words : Teaching physiscs, top down process, scaffolding, critical thinking skills

\begin{abstract}
Abstrak: Penelitian ini merupakan penelitian pengembangan yang bertujuan untuk mengetahui efektifitas perangkat pembelajaran fisika melalui pendekatan pemrosesan top down berbasis scaffolding untuk melatihkan keterampilan berpikir kritis. Perangakt pembelajaran diujicobakan di SMAN 18 Surabaya sampai tahap uji pengembangan awal. Data hasil uji pengembangan awal meliputi data keterlaksanaan pembelajaran, aktifitas siswa, respon siswa, dan keterampilan berpikir kritis siswa yang diperoleh dari lembar observasi. untuk tes keterampilan berpikir kritis diperoleh dari tes. Dari hasil uji pengembangan awal diketahui bahwa proses pembelajaran terlaksana dengan baik, dengan aktifitas siswa yang didominasi oleh diskusi kelompok dalam melakukan eksplorasi konsep. Selain itu respon siswa terhadap pembelajaran sangat baik dimana 60\% siswa merasa sangat mudah memahami cara guru mengajar dan 90\% siswa sangat berminat jika materi diawali dengan identifikasi fakta dari permasalahan. Namun untuk keterampilan berpikir kritis, siswa masih berada pada kategori tidak terampil sampai agak terampil.
\end{abstract}

Kata-kata Kunci : Pembelajaran fisika, pemrosesan top down, scaffolding, keterampilan berpikir kritis

\section{PENDAHULUAN}

Mata pelajaran fisika bertujuan agar peserta didik memiliki kemampuan untuk memupuk sikap ilmiah yaitu jujur, obyektif, terbuka, ulet, kritis dan dapat bekerjasama dengan orang lain, mengembangkan kemampuan bernalar dalam berpikir analisis induktif dan deduktif dengan menggunakan konsep dan prinsip fisika untuk menjelaskan berbagai peristiwa alam dan menyelesaian masalah baik secara kualitatif maupun kuantitatif (BSNP, 2006). Standar Ketuntasan Lulusan (SKL) yang telah ditetapkan oleh pemerintah dalam pelajaran fisika di SMA menuntut siswa untuk melakukan percobaan, antara lain merumuskan masalah, mengajukan dan menguji hipotesis, menentukan variabel, merancang dan merakit instrumen, mengumpulkan, mengolah dan menafsirkan data, menarik kesimpulan, serta mengkomunikasikan hasil percobaan secara lisan dan tertulis (BSNP, 2006).

Kondisi pembelajaran yang tercantum pada SKL mengindikasikan bahwa siswa merupakan agen aktif yang akan mengkonstruksi informasi yang mereka peroleh. Namun sebagian besar guru dalam mengajar fisika masih menggunakan paradigma lama, yaitu pembelajaran fisika yang lebih menekankan pada peranan guru mengajar daripada siswa belajar. Pengetahuan tidak dapat dipindahkan begitu saja dari otak seseorang (guru) ke kepala orang lain (murid).

Berdasarkan hasil obervasi penulis di salah satu SMA RSBI Jawa Timur, diperoleh data kemampuan menganalisis perpaduan dua buah gerak, yaitu gerak lurus berubah beraturan dan gerak parabola yaitu dari 34 siswa hanya 2 orang siswa yang mampu menjawab dengan benar sedangkan 32 lainnya memberikan jawaban salah (Rusli, 2010). Keadaan ini tidak jauh berbeda dengan hasil penelitian TIMSS (Trend International Mathematics Science Study), rata-rata skor prestasi sains siswa Indonesia tahun 1999 berada pada peringkat ke 32 dari 38 negara, tahun 2003 peringkat ke 37 dari 46 negara, dan tahun 2007 di peringkat ke 35 dari 49 negara (TIMSS, 2011). 
Hasil observasi di atas menunjukkan bahwa siswa belum mampu mengambil keputusan dalam memilih jawaban secara tepat melalui hasil konstruksi skemata mereka sebagai argumen dalam menentukan pilihan secara rasional beradasarkan konsep fisika yang telah mereka pelajari. Keadaan ini mengindikasikan bahwa keterampilan berpikir kritis siswa belum terbentuk bahkan bisa jadi setting pembelajaran yang diterapkan di dalam kelas belum pernah mengajarkan keterampilan berpikir kritis. Hal seperti ini tidak hanya dialami oleh siswa di Indonesia, tetapi juga di negara-negara maju seperti Amerika, Inggris, dan Australia. Dalam laporan Association of American Colleges and Universities' (2005) menyatakan bahwa sedikitnya $6 \%$ dari mahasiswa senior di perguruan tinggi dianggap mahir dalam berpikir kritis (Ku, 2009).

Salah satu faktor yang menyebabkan siswa mengalami kesulitan mengkonstruksi skemata adalah dikarenakan prior knowledge jarang dilibatkan dalam pembelajaran. Prior knowledge dapat dilibatkan dengan memberikan masalah yang menantang bagi siswa. Menurut Piaget, pendidikan yang optimal membutuhkan pengalaman yang menantang bagi si pembelajar sehingga proses asimilasi dan akomodasi dapat menghasilkan pertumbuhan intelektual (Hergenhahn \& Olson, 2009). Salah satu pendekatan pembelajaran yang melibatkan prior knowledge adalah melalui pemrosesan top down. Pemrosesan top down mengajukan gagasan bahwa proses pengenalan diawali oleh suatu hipotesis mengenai identitas suatu pola, yang diikuti oleh pengenalan terhadap bagianbagian pola tersebut, berdasarkan asumsi yang sebelumnya telah dibuat (Solso, Maclin, \& Maclin, 2008).

Di ruang kelas yang berpusat pada siswa, guru menjadi pemandu disamping membantu siswa menemukan makna mereka sendiri bukannya mengajari dan menguasai semua kegiatan di ruang kelas (Slavin, 2009).Teknik pemandu yang diberikan adalah teknik scaffolding yang dideskripsikan sebagai perubahan tingkat dukungan selama proses pelajaran berlangsung. Scaffolding akan diberikan jika diperlukan dan akan dikurangi seiring dengan meningkatnya pengetahuan siswa. Para peneliti menemukan bahwa ketika guru dan teman sebaya menggunakan scaffolding dalam pembelajaran kolaboratif, pembelajaran siswa-siswa mendapatkan manfaat (Santrock, 2008).

Mengingat polemik yang dihadapi oleh dunia pendidikan sekarang ini, baik secara intelektual maupun sosial, maka sudah selayaknya sistem pembelajaran berorientasi pada pembentukan pola pikir yang rasional serta kemampuan siswa dalam mempertimbangkan segala sesuatu hal sebelum mengambil keputusan dan tindakan yang merupakan cerminan dari keterampilan berpikir kritis.
Untuk mewujudkan harapan ini maka salah satu solusi alternatif adalah dengan mendesain pembelajaran fisika melalui pendekatan pemrosesan top down berbasis scaffolding untuk melatihkan keterampilan berpikir kritis.

\section{METODE PENELITIAN}

Penelitian ini merupakan penelitian pengembangan dengan desain pengembangan four-D model yang diujicobakan pada tahap uji pengembangan awal. Subjek ujicoba perangkat adalah siswa kelas XI IPA. Pengumpulan data dilakukan dengan menggunakan metode tes dan metode observasi. Metode tes digunakan untuk mengetahui keterampilan berpikir kritis siswa setelah mengikuti pembelajaran melalui pemroessan top down berbasis scaffolding, sedangkan metode observasi digunakan untuk mengungkap keterlaksanaan pembelajaran, aktivitas siswa, dan respon siswa setelah mengikuti pembelajaran. Data yang diperoleh dianalisis melalui Analisis keterlaksanaan pembelajaran. Sedangkan data keterampilan berpikir kritis dianalisis menggunakan rubrik keterampilan berpikir kritis dengan kategori; 1) tidak terampil; 2) agak terampil; 3) terampil; 4) sangat terampil.

\section{HASIL DAN PEMBAHASAN}

\section{Keterlaksanaan Pembelajaran}

Keterlaksanaan pembelajaran fisika melalui pemrosesan top down berbasis scaffolding dideskripsikan pada Gambar 1 berikut:

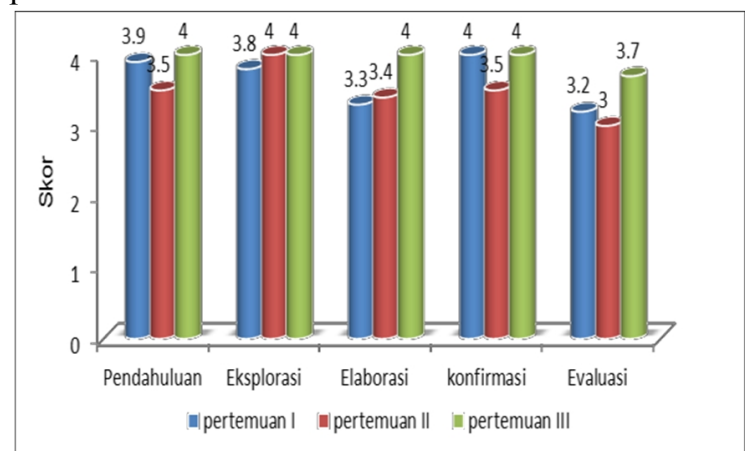

Gambar 1. Hasil pengamatan keterlaksanaan tahapan pembelajaran

Dari Gambar 1 dapat disimpulkan bahwa tahapan pembelajaran pemrosesan top down secara umum dapat terlaksana dengan baik. Pada pendahuluan pertemuan ke dua, demonstrasi jawaban pertanyaan tidak dilaksanakan. Hal ini dikarenakan siswa sudah mendemonstrasikan jawaban tersebut pada pertemuan pertama dan mereka masih mengingat hasil demonstrasinya. Tahap evaluasi yang terlaksana hanya $50 \%$ saja. Pada pertemuan pertama siswa belum mampu mengkomunikasikan pengetahuan yang mereka peroleh, sedangkan pada pertemuan II dan III mereka sudah mampu menyimpulkan pengetahuan yang telah mereka peroleh 
namun guru tidak memberi tugas tambahan pada pertemuan II dan III. Hal ini dikarenakan waktu pembelajaran melebihi jadwal yang telah ditetapkan sebelumnya, selain itu siswa juga mengeluhkan jika diberi tugas tambahan dari sekolah.

\section{Aktivitas siswa}

Aktivitas siswa yang terekam oleh video kemudian diamati oleh peneliti dengan hasil pengamatan dibagi dalam 5 kategori, yaitu: 1) pendahuluan; 2) eksplorasi; 3) elaborasi; 4) konfirmasi; dan 5) evaluasi. Pada tahap pendahuluan, Aktivitas siswa yang paling dominan adalah mendengarkan instruksi, mengamati video dan demonstrasi, setelah itu siswa mengajukan pendapat. Tahap eksplorasi, aktivitas yang paling dominan adalah siswa membaca buku dan mendiskusikan LKS. Pada kegiatan elaborasi, siswa menyampaikan jawaban pertanyaan LKS yang telah mereka diskusikan, sedangkan siswa lain mendengarkan jawaban. Pada tahap konfirmasi, guru memberikan penjelasan dari hasil diskusi siswa dan memberikan apresiasi bagi siswa yang telah menyampaikan jawaban mereka. Pada tahap evaluasi siswa menyimpulkan pengetahuan yang siswa peroleh setelah mengikuti proses KBM, namun pada pertemuan pertama, guru yang terlebih dahulu memberi simpulan dari materi yang telah siswa pelajari. Untuk lebih jelasnya aktivitas siswa dirangkum pada Gambar 2 berikut.

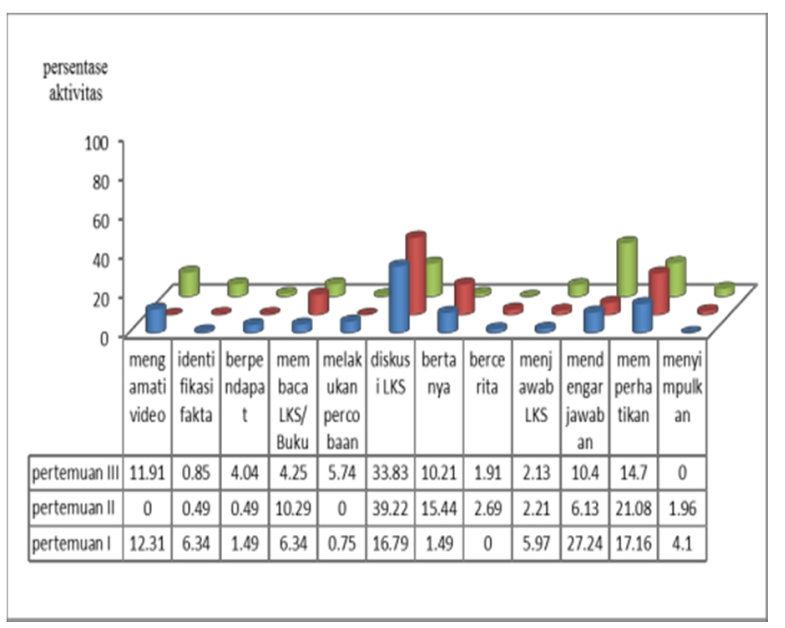

Gambar 2. Frekuensi aktivitas siswa dalam proses KBM

Pada Gambar 2 diperoleh informasi bahwa aktivitas siswa yang dominan pada pertemuan pertama adalah menyelesaikan LKS yang menjadi jembatan bagi siswa untuk memahami konsep momen gaya. Demikian halnya pada pertemuan kedua dan ketiga. Hal menarik yang perlu dijelaskan adalah aktivitas yang persentasenya nol. Proses KBM yang memiliki persentase nol terbanyak adalah pertemuan kedua. Aktivitas mengamati video dan melakukan percobaan tidak terlaksana pada pertemuan kedua. Hal ini tidak terlaksana karena percobaan tersebut sudah dilaksanakan pada pertemuan pertama sehingga siswa cukup dengan mengingat hasil percobaan tersebut untuk melanjutkan aktivitas lain. Selain itu terdapat pula aktivitas nol pada aspek "bercerita" untuk pertemuan ketiga. Aktivitas ini baik ketika bernilai 0, namun pada pertemuan pertama dan kedua masing-masing terdapat $1,91 \%$ dan $2,69 \%$.

Hal ini terjadi karena respon guru terhadap pertanyaan siswa tidak disegerakan sehingga memberi peluang bagi siswa untuk mencari topik lain untuk didiskusikan. Aktivitas lain yang bernilai 0 adalah menyimpulkan. Pada pertemuan pertama, simpulan disampaikan oleh guru mengingat waktu yang digunakan sudah melebihi dari perencanaan, sedangkan pada pertemuan II dan III siswa sudah menyampaikan simpulan sendiri.

\section{Respon siswa terhadap pembelajaran}

Respon siswa terhadap KBM diperoleh dengan memberikan angket respon siswa setelah siswa mengikuti post test. Rekapitulasi respon siswa terhadap kegiatan pembelajaran fisika melalu pemrosessan top down berbasis scaffolding dapat diklasifikasikan dalam 3 hal, yaitu; a) respon siswa terhadap komponen pembelajaran; b) respon siswa terhadap masalah/ tantangan yang ditampilkan oleh guru; c) respon siswa terhadap keterampilan berpikir kritis.

\section{a. Respon siswa terhadap komponen pembelajaran}

Respon siswa terhadap komponen pembelajaran meliputi bahasa dalam buku, materi atau isi buku, contoh-contoh soal dalam buku, lembar kegiatan siswa, dan cara guru mengajar. Hasil respon siswa tersebut disajikan dalam Gambar 3 berikut ini.

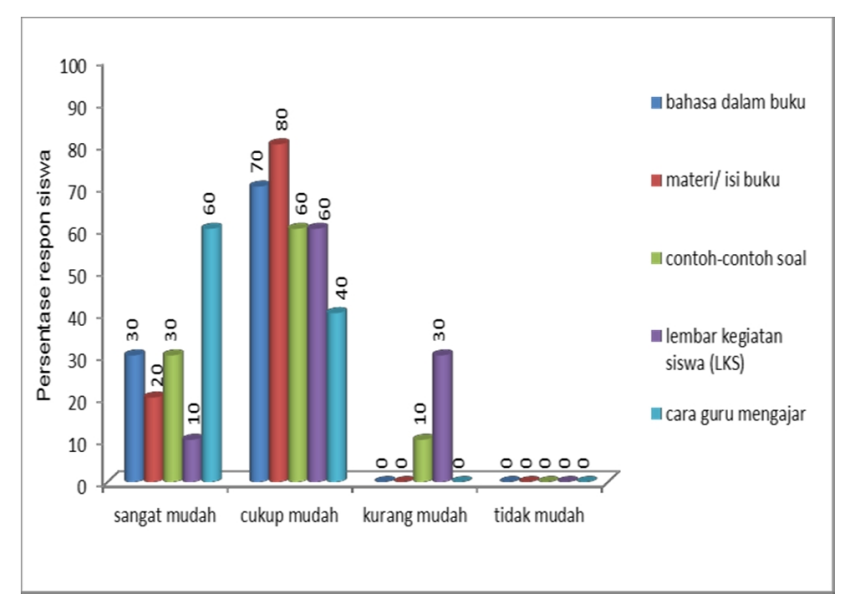

Gambar 3. Respon siswa terhadap kemudahan komponen pembelajaran.

Dari Gambar 3 di atas dapat dijelaskan bahwa komponen kebahasaan dan konten dalam buku siswa cukup mudah untuk dipahami siswa, sedangkan lembar kerja siswa terdapat $30 \%$ siswa yang menganggap kurang mudah. 
Hal ini disebabkan karena pada LKS terdapat beberapa pertanyaan yang terkait dengan manipulasi variabel matematis yang melibatkan 3 persamaan. Selain itu, siswa dituntut untuk aktif mencari informasi dalam menyelesaikan pertanyaan yang ada pada LKS baik melalui percobaan ataupun dengan membaca buku siswa.

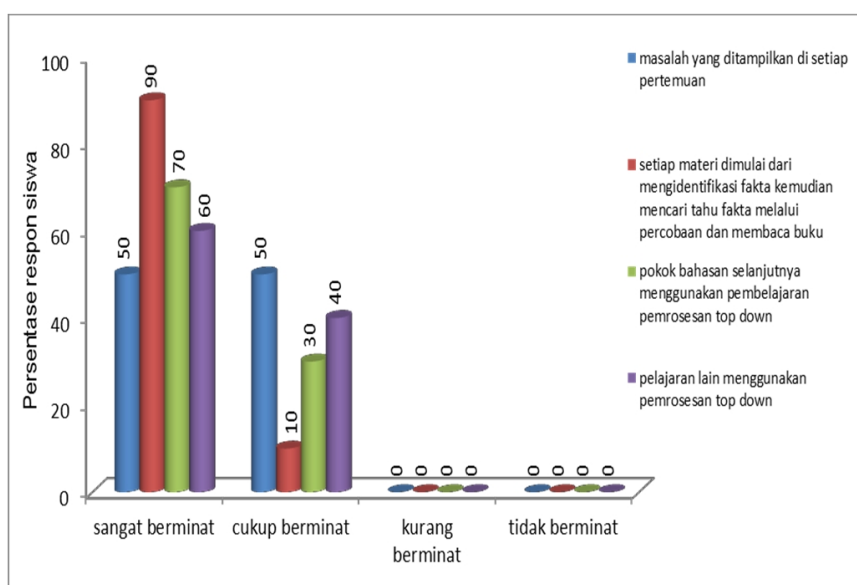

Gambar 4. Respon siswa dalam mengikuti pembelajaran

\section{b. Respon minat siswa dalam mengikuti pembelajaran}

Respon minat siswa terhadap pembelajaran dideskripsikan pada Gambar 4. Dari Gambar 4 di atas diperoleh gambaran bahwa 100\% siswa berminat untuk mengikuti pembelajaran melalui pemrosesan top down dan mereka berharap agar materi fisika selanjutnya diajarkan dengan cara yang sama, bahkan pelajaran yang lain pun sebaiknya diajarkan melalui pemrosesan top down.

c. Respon siswa terhadap komponen keterampilan berpikir kritis

Untuk mengakses respon siswa terhadap keterampilan berpikir kritis, mereka diberi pertanyaan penilaian siswa terhadap keterampilan berpikir kritis yang komponennya meliputi: mengidentifikasi dan menjelaskan masalah, menginterpretasi berdasarkan asumsi, mengidentifikasi konsep/hokum yang berlaku, menggabungkan konsep/hukum yang berlaku, dan mengevaluasi berdasarkan hasil analisis. Hasil respon tersebut kemudian ditampilkan dalam Gambar 5 berikut:

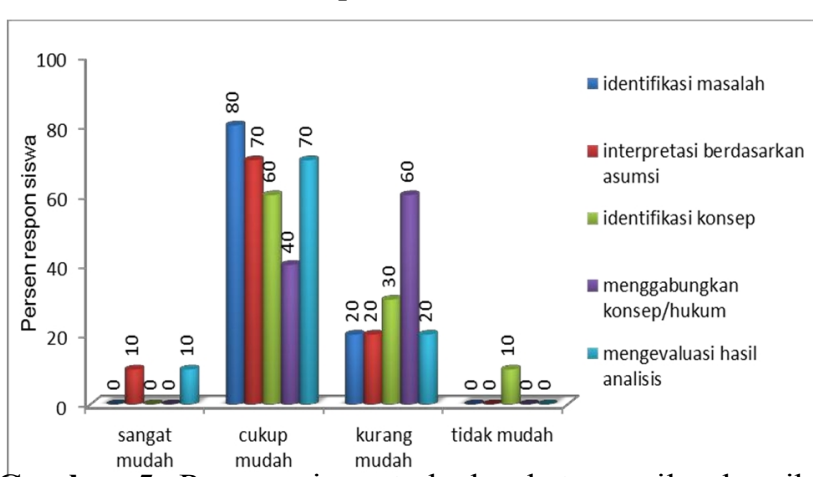

Gambar 5. Respon siswa terhadap keterampilan berpikir kritis.
Dari Gambar 5 di atas diperoleh gambaran bahwa dalam mengidentifikasi fakta, menginterpretasi berdasarkan asumsi, identifikasi konsep, dan mengevaluasi hasil analisis bagi siswa adalah cukup mudah, tetapi untuk menggabungkan konsep dan hukum fisika, $60 \%$ berpendapat kurang mudah. Hal ini dibuktikan pada hasil tes keterampilan berpikir kritis dimana kemampuan mereka dalam manipulasi variabel matematis masih sangat lemah. Hal ini dibuktikan dengan jumlah scaffolding yang begitu tinggi pada pertemuan ke dua. Proses KBM ini mendapatkan respon yang positif dari siswa.

Berdasarkan Gambar 4, respon siswa terhadap masalah atau tantangan yang ditampilkan adalah 90\% sangat berminat, bahkan $70 \%$ siswa berminat jika materi fisika selanjutnya diajarkan melalui pemrosesan top down berbasis scaffolding. Selain itu, respon siswa terhadap komponen pembelajaran pada umumnya mengatakan mudah, namun terdapat $30 \%$ siswa yang mengalami kesulitan dalam menyelesaikan LKS.

\section{Keterampilan berpikir kritis}

Tes keterampilan berpikir kritis didesain sebagai akumulasi dari sejumlah pertanyaan yang mengelaborasi berbagai komponen kognitif. Dari hasil tes tersebut diperoleh data keterampilan berpikir kritis siswa sebagai berikut:

\begin{tabular}{|c|c|c|c|c|c|c|c|c|c|}
\hline \multicolumn{1}{|c|}{$\begin{array}{c}\text { No } \\
\text { indikator } \\
\text { soal }\end{array}$} & 1 & 2 & 3 & 4 & 5 & 6 & 7 & $\begin{array}{c}\text { Rata } \\
\text {-rata }\end{array}$ \\
\hline \multirow{2}{*}{$\begin{array}{l}\text { Rata- } \\
\text { rata }\end{array}$} & $\begin{array}{l}\text { Pre } \\
\text { test }\end{array}$ & 1 & 1 & 1 & 1 & 1 & 1 & 1 & 1 \\
\cline { 2 - 9 } & $\begin{array}{l}\text { Post } \\
\text { test }\end{array}$ & 1,8 & 2 & 1,6 & 1,3 & 1,2 & 1,5 & 1,6 & 1,6 \\
\hline
\end{tabular}

Tabel 1 menunjukkan hasil pre test keterampilan berpikir kritis siswa adalah tidak terampil sedangkan posttest menunjukkan bahwa siswa berada pada rentang tidak terampil sampai agak terampil. Hal ini mengindikasikan bahwa keterampilan berpikir kritis dapat dilatihkan kepada siswa melalui pendekatan pemrosesan top down berbasis scaffolding. Hasil yang belum signifikan menunjukkan adanya kendala yang dihadapi selama proses KBM. Kendala tersebut meliputi kemampuan siswa dalam mengoperasikan manipulasi variabel secara matematis, kemampuan siswa mengkonstruksi konsep- konsep dan hukum fisika sertaset mental siswa yang tidak serta merta dapat diubah dalam pertemuan singkat.

Untuk mendeskripsikan hasil di atas, maka penulis membagi data tes keterampilan berpikir ke dalam dua aspek: a) skor rata-rata item keterampilan berpikir kritis; dan b) skor rata-rata keterampilan berpikir kritis siswa.

\section{a. Rata-rata skor item soal keterampilan berpikir kritis}


Skor rata-rata item soal menunjukkan apakah item tersebut mudah atau sukar dengan kategori skor; 1) tidak terampil; 2) agak terampil; 3) terampil; 4) sangat terampil.

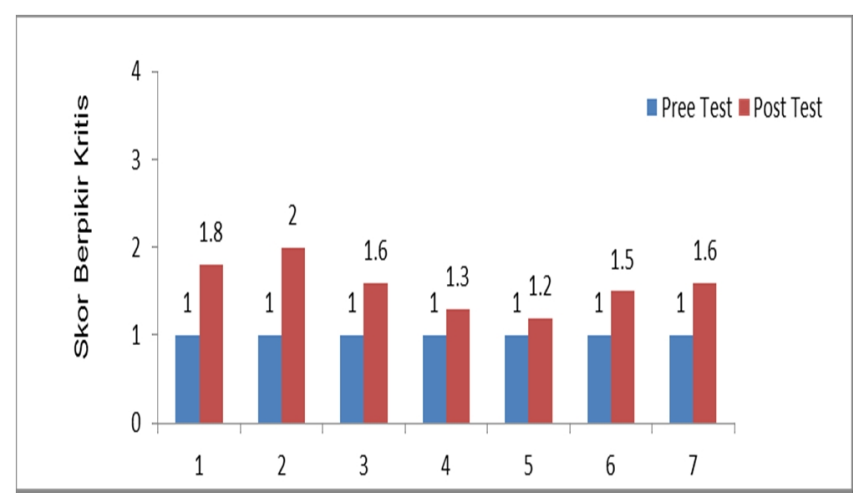

Gambar 6. Skor setiap indikator soal keterampilan berpikir kritis

Dari Gambar 6 dapat dijelaskan bahwa skor ratarata item soal berpikir kritis pre test adalah 1 sedangkan skor rata-rata item post test bervariasi pada rentang 1 sampai 2 . Ini menandakan bahwa siswa berada pada kategori agak terampil. Item 4 dan 5 adalah item yang memiliki skor terendah, Hal ini mengindikasikan bahwa siswa masih sangat lemah dalam melakukan manipulasi variabel matematis untuk menghitung variabel yang diperlukan. Sedangkan item 5 merupakan implikasi dari item 4. Dengan menjawab item 4 , dengan mudah siswa dapat menjawab item 5. Soal yang memiliki skor tertinggi adalah item 2 dan item 1 masing masing soal hipotesis dan soal yang menuntut siswa mampu memahami makna dari kata kunci suatu permasalahan. Siswa memperoleh skor pada rentang 1 sampai 2 bukan berarti mereka tidak menjawab dengan benar, tetapi lebih kepada kurangnya kemampuan siswa memberi argumen dari setiap jawaban mereka.

\section{b. Rata-rata skor berpikir kritis siswa}

Rata-rata skor berpikir kritis mengindikasikan pencapaian yang siswa peroleh dalam menyelesaikan soal berpikir kritis setelah mengikuti proses KBM. Secara deskripsi pencapaian tersebut dapat dijelaskan melalui rubrik berpikir kritis. Berikut ini ditampilkan Gambar 7, skor rata-rata skor berpikir kritis siswa pretest dan posttest tinjauan taksonomi bloom tidak mutlak dikatakan terampil berpikir kritis.

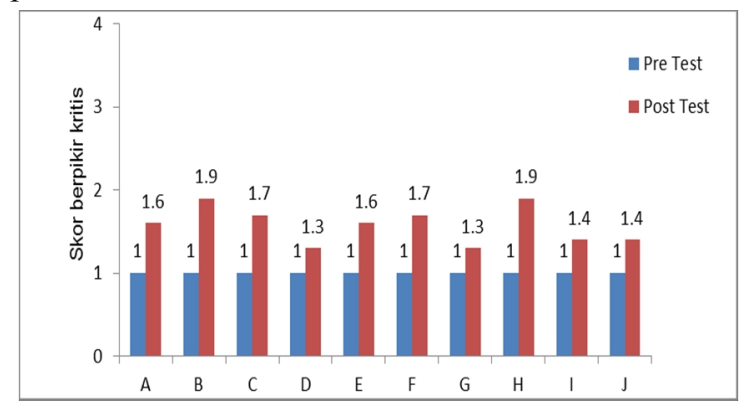

Gambar 7. Skor keterampilan berpikir kritis siswa

Dari Gambar 7 diperoleh informasi bahwa skor pretest siswa sama-sama berada pada skor 1 dengan kategori tidak terampil. Sedangkan skor posttest berada pada rentang 1 sampai 2 yang berarti siswa berada pada kategori antara tidak terampil sampai agak terampil. Siswa yang memperoleh skor tertinggi berdasarkan kategori keterampilan berpikir kritis adalah B dan $\mathrm{H}$ sedangkan skor ditinjau dari segi taksonomi bloom adalah B dan F. Perlu dipahami bahwa perbedaan ini disebabkan oleh kriteria rubrik berpikir kritis. Siswa yang menjawab benar dari suatu permasalahan, sedangkan soal hasil belajar masing-masing menuntut satu konsep fisika.

Berdasarkan data hasil pre test dan post test keterampilan berpikir kritis, rata-rata pre test keterampilan berpikir kritis siswa adalah tidak terampil sedangkan hasil post test siswa tersebut berada pada rentang antara tidak terampil hingga agak terampil. Kategori agak terampil tidak berarti jawaban mereka salah, tetapi kualitas jawaban yang siswa tuliskan belum memenuhi syarat untuk dikategorikan terampil dan sangat terampil. Hal ini sejalan dengan respon siswa terhadap keterampilan berpikir kritis pada Gambar 5 yang memperlihatkan bahwa $60 \%$ mengalami kesulitan dalam menggabungkan konsep atau hukum fisika dalam menyelesaikan suatu persoalan.

Berdasarkan data hasil pre test dan post test keterampilan berpikir kritis, rata-rata pre test keterampilan berpikir kritis siswa adalah tidak terampil sedangkan hasil post test siswa tersebut berada pada rentang antara tidak terampil hingga agak terampil. Kategori agak terampil tidak berarti jawaban mereka salah, tetapi kualitas jawaban yang siswa tuliskan belum memenuhi syarat untuk dikategorikan terampil dan sangat terampil. Hal ini sejalan dengan respon siswa terhadap keterampilan berpikir kritis pada Gambar 5 yang memperlihatkan bahwa $60 \%$ mengalami kesulitan dalam menggabungkan konsep atau hukum fisika dalam menyelesaikan suatu persoalan.

Fakta hasil tes keterampilan berpikir kritis ini tidak lepas dari pengaruh pembelajaran di sekolah. Berdasarkan hasil wawancara dengan siswa, diperoleh informasi bahwa selama ini fisika diajarkan melalui 
pemberian contoh soal disertai latihan. Dengan demikian, set mental yang tertanam pada siswa menganggap fisika sebagai pelajaran yang hanya mengajarkan persamaan dan perhitungan serta contoh dan penyelesaian soal dari guru. Pemberian contoh soal, disertai penyelesaian menjadi budaya dalam pembelajaran fisika. Akibatnya guru menjadi penentu kebenaran mutlak yang sama halnya menutup peluang bagi siswa untuk berpikir kritis (Tyler, 2008).

Implementasi pembelajaran fisika melalui pendekatan pemrosesan top down pada pertemuan pertama menyulitkan siswa memecahkan masalah. Hal ini terjadi karena set mental siswa berbeda dengan apa yang mereka peroleh melalui pemrosesan top down. Dengan kata lain, budaya dan pendidikan memiliki pengaruh lebih kuat pada perkembangan anak-anak (Santrock J. W., 2008). Selama ini KBM fisika hanya mengajarkan contoh soal dan latihan yang melibatkan satu konsep fisika. Akibatnya, siswa yang mengikuti KBM pemrosesan top down mengalami kesulitan dalam menjelaskan suatu fakta yang melibatkan beberapa konsep dan hukum fisika. Lebih tepatnya dikatakan bahwa mereka mempunyai sebuah skema permasalahan, atau pengetahuan tentang beberapa masalah tertentu dan langkah pemecahannya, yang mereka gunakan dalam mengklasifikasikan masalah (Jeanne Ellis, 2012). Set mental membuat siswa berpegang kaku pada asumsiasumsi dan pendekatan-pendekatan kuno yang menghalangi mereka untuk mencoba pendekatan atau solusi yang lebih baik dan lebih efisien (Carole wade, 2008).

Hasil penelitian ini menunjukkan bahwa untuk melatihkan keterampilan berpikir kritis sampai pada tingkat terampil khususnya kepada siswa yang memiliki set mental dan budaya penghambat berpikir kritis tidak cukup hanya dalam beberapa kali pertemuan, melainkan dibutuhkan waktu untuk membiasakan dan melatihkan sikap kritis siswa. Hal ini didukung hasil penelitian (Rob Wass, 2011) yang menyatakan bahwa dibutuhkan dua sampai tiga tahun agar siswa mampu mengintegrasikan ide-ide mereka dan menerapkan berpikir kritis untuk hal- hal yang baru.

\section{SIMPULAN}

Berdasarkan hasil uji pengembangan awal perangkat pembelajaran dan temuan-temuan pada proses pembelajaran, maka dapat disimpulkan bahwa Pembelajaran fisika melalui pendekatan pemrosesan top down berbasis scaffolding untuk melatihkan keterampilan berpikir kritis dengan perangkat yang meliputi RPP, LKS, buku siswa, dan tes keterampilan berpikir kritis telah valid dan layak untuk dilanjutkan pada tahap pengembangan selanjutnya (the quantitative developmental testiing) dengan mempertimbangkan beberapa hal yang akan mendukung keterlaksanaan pembelajaran, seperti bagaimana memaksimalkan pemberian scaffolding dalam melatih keterampilan berpikir kritis siswa agar lebih baik.

Dari temuan hasil penelitian ini dapat disarankan beberapa hal, diantaranya; 1) Keterbatasan siswa dalam mengoperasikan manipulasi variabel secara matematis sebagai aspek pendukung dalam melatih keterampilan berpikir kritis memerlukan alokasi waktu tertentu. 2) Dari temuan-temuan di atas, perlu diadakan penelitian lanjutan tentang: a) analisis ketidakmampuan siswa dalam menyelesaikan manipulasi variabel secara matematis lebih dari dua variabel; b) faktor-faktor penghambat keterampilan berpikir kritis; c) bagaimana mengembangkan teknik scaffolding dalam melatihkan keterampilan berpikir kritis; d) dan untuk mendesain pembelajaran berbasis keterampilan berpikir kritis, perlu adanya kajian tentang proses berpikir kritis siswa.

\section{DAFTAR PUSTAKA}

BSNP. (2006). BSNP-Indonesia Retrieved October, 19, 2011,from http://bsnp-indonesia.org/id/?page_id=103/

Ellis, J., \& Ormrod. (2012). Human learning (6 ed.). USA: Pearson.

Hergenhahn, B. R., \& Olson, M. H. (2009). Theories of Learning. Jakarta: Kencana.

$\mathrm{Ku}, \mathrm{K}$. Y. L. (2009). Assessing students' critical thinking performance: Urging for measurements using multiresponse format. ELSEVIER, 70-76. doi: 10.1016

Rusli, M. A. (2010). Diagnostik gerak peluru. Surabaya: Program Pascasarjana UNESA.

Santrock, J. W. (2008). Educational Psychology. New York: McGraw Hill.

Slavin, R. E. (2009). Psikologi Pendidikan. Boston: Allyn and Bacon.

Solso, R. L., Maclin, O. H., \& Maclin, M. K. (2008). Cognitive psychology. Jakarta: Erlangga.

TIMSS, T. (2011). Kementrian Pendidikan Nasional Badan Penelitian dan Pengembangan Retrieved October, 18, 2011, from http://litbang.kemdiknas.go.id

Tyler, K. M., Uqdah, A. L., Dillihunt, M. L., Beatty, H., Connor, T., \& Gadson, N. (2008). Cultural discontinuity: Toward a quantitative investigation of a major hypothesis in education. Educational Researches, 280-297. Wass, R., Harland, T., \& Mercer, A. (2011). Scaffolding critical thinking in the zone of proximal development. Higher Education Research \& Development, 317-328. 